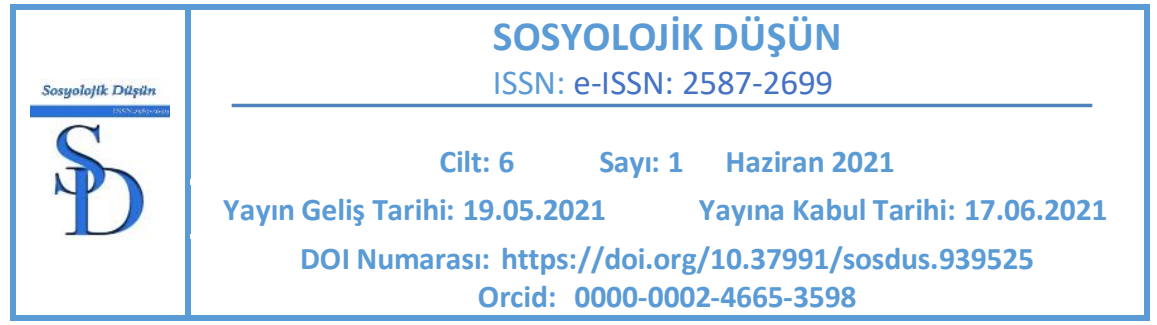

\title{
INDUSTRIAL REVOLUTION AND DEVELOPMENT AS A MODEL IN THE DEVELOPMENT OF TURKISH INDUSTRY DURING THE OTTOMAN EMPIRE AND THE FOUNDATION PERIOD OF THE REPUBLIC
}

\section{Sefa Salih AYDEMiR*}

\begin{abstract}
Before the Industrial Revolution, which is stated to have started in Great Britain in Europe in the 18th century, many social events occurred in different parts of the continent. As a result of these social events that lasted for at least two centuries, the capitalization process began, starting from the rural areas. As a consequence of the Industrial Revolution, searches for raw materials and markets and the competition in this field affected the Ottoman Empire the most. While the Ottoman Empire survived with traditional agricultural production methods until the 18th century, it was dragged into a state crisis after this date, especially due to the deterioration in the land regime and the lost wars. Being aware of the industrial movements in Europe, the Ottoman Empire gave priority to the fields of military industry. Established as the heir to the Ottoman Empire, the Republic of Turkey inherited an underdeveloped and economically bad legacy, whose industry was in the hands of non-Muslims. After the war of independence, the priority of Ghazi Mustafa Kemal and the founding staff was to catch up with the Industrial Revolution experienced in Europe and to establish a fully independent economy and a developed national industry despite all kinds of impossibilities.
\end{abstract}

Keywords: Europe, Industrial Revolution, Turkish Industry.

Dr. Öğr. Üyesi, Adıyaman Üniversitesi, Fen-Edebiyat Fakültesi, Sosyoloji Bölümü, saydemir@adiyaman.edu.tr 
OSMANLI DEVLETI VE CUMHURIYET'IN KURULUŞ DÖNEMI TÜRK SANAYISININ GELIŞMESINDE MODEL OLARAK SANAYI DEVRIMI VE GELişiMi

\begin{abstract}
$\ddot{O z}$
İngiltere merkezli olarak Avrupa'da 18. yüzyılda başladığı ifade edilen Sanayi Devrimi öncesi kıtanın farklı bölgelerinde birçok sosyal olaylar meydana gelmiştir. En az iki asır boyunca süren bu toplumsal olaylar sonucunda kırsal kesimden başlamak üzere kapitalistleşme süreci başlamıştır. Sanayi Devrimimnin bir sonucu olarak hammadde ve Pazar arayışları ve bu alanda yaşanan rekabet en çok Osmanlı Devleti'ni etkilemiştir. Osmanlı Devleti 18. Yüzyıla kadar geleneksel tarıma dayalı üretim yollarıyla ayakta kalırken, bu yüzyıldan sonra özellikle toprak rejiminde gözlenen bozulma ve kaybedilen savaşlar nedeniyle bir devlet krizine doğru sürüklenmiştir. Avrupa'da yaşanan endüstri hareketlerinden haberdar olan Osmanlı Devleti önceliği askeri sanayi alanlarına vermiştir. Osmanlı İmparatorluğunun varisi olarak kurulan Türkiye Cumhuriyeti, az gelişmiş ve sanayisi gayrimüslimlerin elinde olan ekonomik olarak kötü bir miras devralmıştır. Millî mücadele sonrası Gazi Mustafa Kemal ve kurucu kadronun önceliği, Avrupa'da yaşanmış olan Sanayi İnkılabını yakalamak, her türlü imkansızlığa rağmen tam bağımsız bir ekonomi ve gelişmiş bir milli sanayi kurmak olmuştur.
\end{abstract}

Anahtar Kelimeler: Avrupa, Sanayi devrimi, Türk sanayisi.

\title{
1. GíRiş
}

The desire to possess and the lust for power have been described by Immanuel Kant as being incompatible with the natural. Although the lust for authority is contrary to the natural structure of the human being, it is such a strong impulse that this feeling is the first step in the transition from barbarism to civilization (Veysal, 2006). Until the utilization of money in the 7th century BC, inequality between social classes (nobles, craftsmen, peasants) was relatively avoidable. For example, in Athens, one of the ancient Greek city-states, the economic 
imbalance between classes could somehow be prevented; as the nobles owning vast and fertile lands that were out of proportion to the peasant population allowed the peasants to obtain enough crops to survive in these lands and the surplus products were distributed to the peasants due to the inadequacy of accumulation technology (Goz, 2010).

With the introduction of money, the nobles converted their surplus products into money and kept them, which caused the peasants to lose significant income (Bonnard, 2004). Apart from this, the peasants who could not pay their debts due to the emerging interest system and the high interest on their debts lost their lands and became slaves over time (Okte, 2008).

Having lost all kinds of social security, the peasant class turned into political opposition and started rebellion movements in regions such as Megara and Samos (Savas, 2000). The main signs of industrial and commercial life in the 7th century $B C$ emerged as the beginning of the money economy and slavery. Hence, the developing economic life has led to the emergence of a middle class (merchants, industrialists, sailors, workers, small craftsmen) between aristocrats and peasants. This middle class subsequently undermined the foundations of the Greek state and, in turn, the aristocratic structure. Upon the aristocrats' attempts to gain effectiveness in economic life, the middle class, with the support of the peasants, demanded some rights from the aristocrats. Thus, a class struggle began, just like in Rome (Mansel, 1984).

There was much in common in the formation of the slave states in Rome and Ancient Greece. In this era (6th century $\mathrm{BC}$ ), the Romans lived in clans and tribes. The Roman community was formed by the union of these tribes. The administrative structure, consisting of the king, who is the head of the tribe, and the council of elders, transformed into the Senate over time. A significant part of the population remained outside this minority administration. These are 
Industrial Revolution and Development As a Model in the Development of Turkish Industry During the Ottoman Empire and the Foundation Period of the Republic Gens, Clientes, and Plebs. Over time, these groups gained the right to be a soldier and to vote and obtained citizenship (Umur, 1982).

Civil conflicts such as the Solonian revolution in Ancient Greece* and that of the "Gracchus brothers" in Republican Rome ${ }^{\dagger}$ had an element of open class conflict, aimed not only at getting rid of oligarchic powers in the senate but also intending to remove the heavy debt burden on the farmer. As the Gracchus brothers demanded an equal distribution of land on behalf of the nonaristocratic masses and consequently gained the support of the people, they also tried to transform the city-states into a primitive kind of democracy. In their attempt to dominate the Plebeian assembly over the Senate, the Gracchus brothers were concerned only with the fate of republican Rome, not the general public. In fact, their local conflict had no effect on the periphery of Rome and beyond its satellite communities on the Italian peninsula (Umur, 1982).

Another rebellion during this period in Rome was the Spartacus uprising that started in 74 BC (Encyclopedia of Socialism and Social Struggles-STMA, 1988; Mitropolski \& Zubritski, 2006). Here, too, the political power reacted violently through its armies by disregarding the social and economic status of the slaves, due to the incompatibility of its material interests with the peasants

\footnotetext{
* At the end of the 7th century BC, as the economy developed in the Attica region, whose capital was Athens, the power was passing to the prominent landowners. As this privileged group seized the best lands of Attica, the people were getting poorer. With change expanding, usury was emerging, debt enslavement was becoming common. At the beginning of the 6th century $\mathrm{BC}$, serious conflicts arose among the enslaved people. In this case, the aristocracy had to compromise its rights. In 594 BC, Solon was elected archon and assumed the role of arbitrator to avoid conflict. The land mortgage was repealed, old debts were voided, and the indebted citizens were forbidden to be sold as slaves if they could not pay their debts (Mitropolski \& Zubritski, 2006).

+ The Gracchus brothers, Tiberius and Gaius, were martyred in ancient Rome for social reform. Tiberius was killed by the Roman Senate for trying to adapt the system to the lower classes by limiting the large farms of the upper-class Patricians and trying to make the so-called lower-class plebs compete with the patricians. Gaius and his entourage were also killed in $121 \mathrm{BC}$ for the same reasons by the Roman senate, mostly patricians (Plutarkhos, 2001).
} 
representing the political opposition (Westermann, 1955). The more universal demands of freedom would manifest themselves as social transitions and changes in the public consciousness over the course of centuries (Bookchin, 2012).

In medieval Europe, great migrations from the east and north severely shook life on the continent, and most communities gathered in armed forts or besieged areas. As a result, lifestyles based on hierarchical as well as class structures have been fixed into forms of static pyramids that will remain essentially unchanged for centuries. Social life was organized around selfsufficient mansions, where lords with innate social and economic privileges who held the land as vassals of higher lords to whom they were attached for reasons such as financial support, personal oath of loyalty, military service debt (Bookchin, 2012).

Serfs, family groups tied to the land in the villages, were neither slaves nor fully free. Besides allocating most of the crops they harvested from the land to local lords, serfs were also responsible for a large number of personal services, giving gifts to the manor on certain days, and arming when necessary. In return, the lords were obligated to protect them against all kinds of external dangers (Bookchin, 2012).

Local merchants, artisans, peasants, and serfs were intertwined, in selfdiscipline, in a world largely settled at the base of feudal society. Therefore, as in antiquity, social conflicts rarely spread out of isolated places until the middle of the Middle Ages (Bookchin, 2012).

However, since the 14th century, the development of urban life, opening of forested lands, end of great migrations, acceleration of trade changed the balance in favor of the ruling group, and a distinction was formed among the wealthy merchants and artisans according to their material assets. For Europe, the rise of Christianity has also been a unique ideological revolution. The 
Industrial Revolution and Development As a Model in the Development of Turkish Industry During the Ottoman Empire and the Foundation Period of the Republic Church, which was a unifying force at first, began to reflect the emerging conflicts in exaggeration when the feudal society started to lose its power in this age (Bookchin, 2012; Kocadaş, 2021).

The first major eruption in the Late Middle Ages was the English Peasants' Revolt of 1381 , led by Wat Tyler and John Ball. ${ }^{\ddagger}$ This period witnessed popular uprisings that were difficult to suppress, often beginning as direct attacks on the privileges of the Church. The plague epidemic, known as the Black Death, reduced the existing workforce and caused chronic peasant revolts intending to get better financial gain. With these movements, which reached dimensions that were almost never seen in previous periods of history, they were united against local governments and bishops in England, Bohemia, Germany, and France (Bookchin, 2012).

Table 1: Some Important Popular Movements in Europe from This Date to The French Revolution Are as Follows (Berce, 2003; Bookchin, 2012):

\begin{tabular}{lll}
\hline Origin & Name of the Revolt & Year \\
\hline England & Lollard Movement & 1384 \\
Prague & Hussite Revolution & 1419 \\
Bohemia & Taborite Rebellion & $1420-1434$ \\
Germany & Luther Reforms & $1517-1521$ \\
Sweden & War of Independence: Gustavus Vasa & 1523 \\
Germany & Peasant Wars: Thomas Muentzer & 1525 \\
Germany & Muenster Rebellion: Leyden John, Jan & \\
& Matthijs & 1535 \\
England & Tudor Rebellions & $1553-1558$
\end{tabular}

\footnotetext{
\# This uprising challenged not only the injustices of the time but also the literal privilege and hierarchical center of feudal society. In May 1381, peasants in northern London, armed with axes, bows, and arrows, revolted under the leadership of Wat Tyler. By seizing Canterbury, they freed John Ball from prison, who had previously been imprisoned by the government for his provocative speeches. On June 12, 1381, about 20,000 peasants gathered outside the city walls and requested a meeting with the 14year-old King Richard II. After the king said that he accepted their demands and had them dispersed, he had the leaders of the uprising killed. This rebellion, which failed in terms of social revolution, enabled the abolition of the head tax in 1382 in order to prevent new uprisings (Gok, 2007).
} 


$\begin{array}{lll}\text { France } & \text { French Civil War: Henry of Navarre } & 1562-1598 \\ \text { Holland } & \text { William the Silent Revolution } & 1572-1584 \\ \text { England } & \text { Scottish Reformation } & 1560 \\ \text { England } & \text { The Gunpowder Conspiracy: Guy } & \\ & \text { Fawkes } & 1607 \\ \text { England } & \text { The Great Rebellion: Oliver Cromwell } & 1640-1660 \\ \text { England } & \text { Glorious Revolution } & 1688\end{array}$

These crisis periods in the Middle Ages; also witnessed creative social, economic, and technological developments that paved the way for the coming of the New Age. The collapse of the Eastern Roman Empire and the domination of Constantinople by the Ottoman Turks in 1453 caused a great impact and change in the fields of economy, culture, and religion in Europe (Cihangir, 2004; Alganer and Cetin, 2007). In this age, Protestantism began to spread rapidly in Europe, the unity of the church weakened, and with the Renaissance and Reform Movements, the idea of the Christian Community left its place to the European States System based on the nation-state phenomenon (Delanty, 2005; Halecki 2000).

The efforts to create unity in Europe gained momentum with the search for markets that increased as a result of the industrial revolution towards the end of the 18th century (Karluk, 2007). J.J. Rousseau ${ }^{\S}$ (1712-1778), one of the intellectual designers on this subject, argued that by establishing a supranational federal union in Europe, it would be possible to resolve the ongoing conflicts between states and to ensure peace. These ideas of his also constituted an important resource for the integration of today's Europe

\footnotetext{
$\S$ J.J. Rousseau, in the introduction of his work published in Amsterdam in 1761, titled "Extrait de Projet de Paix Perpetuelle de M. L'Abbe de Saint Pierre, par J.J. Rousseau, citoyen de Geneve", said regarding the project for the "European Union" that "For the universal and permanent peace of humanity, there has never been such a great and beautiful project involving all the nations of Europe. It is not possible to find another writer who can reach the reality of this project..." (Cited by: Yildirim, 2007; Yalvac 2007).
} 
Industrial Revolution and Development As a Model in the Development of Turkish Industry During the Ottoman Empire and the Foundation Period of the Republic (Canbolat, 2007). At the end of the 18th century, Europe faced the French Revolution (1789-1795), one of the greatest and most influential revolutions in history (STMA, 1988; Hobsbawm, 2009).

The French Revolution has often been seen as the par excellenceof revolutions. This interpretation was so entrenched in later revolutionary social thoughts that the French Revolution became a kind of template for subsequent revolutionary movements (Bookchin, 2012). The French Revolution began with an uprising neither of the peasantry nor the various bourgeois groups, but, ironically, of the nobility, whose financial situation was broken due to costly wars, internal consolidation, rising prices, excessive spending allocated to the privileged strata in the palace (Bookchin, 2012).

The driving forces of the French Revolution, on the other hand, were thanks to the extraordinary alliance of the urban bourgeoisie, which was uncomfortable with the aristocratic structure, and the peasant and the working-class that were crushed under heavy tax burden (Lee, 2004). In this sense, the most important power that achieved great success, that determined the outcome of the revolution, and that brought the age of feudalism to an end, was again the peasant class (Duman, 2008). As a far-reaching driving force devoid of organization, the peasant revolution in France also guided other social movements (Hobsbawn, 1998).

Liberalism has built its foundation on the nation-states that emerged with the collapse of the medieval order. Nation-states have taken the place of the universal Christian world over time (Akca, 2005 ; Cetin, 2002). The concepts of reason, rational individual, and nationality of a country have come to the fore (Aktan, 1995). The Declaration of Human Rights, which was announced during the American War of Independence (1775-1783) in the 18th century, and the French Revolution accelerated the liberalism process, and this wave spread all over Europe (Duman, 2008). 
The Industrial Revolution (1750-1850), concurrent with the French Revolution, played an important role in the development of liberalism as well by providing the necessary structural and intellectual changes. This revolution also brought the bourgeoisie to power (Cetin, 2002).

The Industrial Revolution started for the first time in the world, in England, where there was a large capital increase thanks to the rapidly expanding international foreign trade volume, and the mechanization of the production stage with the contribution of technical inventions (Kucukkalay, 1997; Rostow, 1970; Hayes, 1939; Deane, 2000; Smith 2009; More, 2000). The revolution that started in England soon spread to America via Western Europe (Maillet, 1983; Pierce, 2005).

Despite its important benefits, the Industrial Revolution also led to social problems, as it created a working class that was unemployed, poor, working very cheaply and in bad conditions for very long periods in the background (Hobsbawm, 1999). The emergence of social movements in real terms started with the working-class movements organized as a consequence of the negativities brought by the Industrial Revolution (Onder, 2003). Competition, new colonial and permanent market searches for necessary raw materials; have led to civil wars and revolutions (Cetin, 2002). The environment of social turmoil, which continued for more than 100 years, was institutionalized and settled with the industrial society and new social strata that emerged after a while with structural changes.

Table 2: Effects of the Industrial Revolution.

\begin{tabular}{lc}
\hline \multicolumn{1}{c}{ Industrial Revolution } \\
\hline \multicolumn{1}{c}{ Intellectual Dimension (Aron; } & $\begin{array}{r}\text { Economic and Social Dimension } \\
\text { (Hamitogullari, 1986) }\end{array}$ \\
\hline $\begin{array}{l}\text { Change in the understanding of } \\
\text { time and space }\end{array}$ & The rapid increase in technical inventions \\
$\begin{array}{l}\text { Change in the perspective of } \\
\text { nature and human }\end{array}$ &
\end{tabular}


Industrial Revolution and Development As a Model in the Development of Turkish Industry During the Ottoman Empire and the Foundation Period of the Republic

Tendency to material gains

Rationalism

Individualism
Overproduction increase in the agricultural field Immigration to the cities Labor force growth and falling wages New inventions and expanding trade Europe's enrichment

In the new social structure that emerged with the Industrial Revolution, the bourgeoisie came out stronger and adopted the understanding of the state that would strengthen itself and keep itself strong (Cetin, 2002). The bourgeoisie tried to spread the freedoms brought by the industrial revolution, such as private property and free enterprise, in every field. Consequently, free enterprise and capitalization, along with other developments, caused liberalism to settle on an economic platform (Satrk, 1994).

Industrial capitalism replaced commercial capitalism, and a revolution begun in social and economic relations as well. In this environment, employers and working classes emerged with new statuses, and great economic imbalances occurred between classes (Selik, 1998; Kocadaş, 2010a). With the mechanization, a large fraction of the workers became unemployed, and as a consequence of impoverishment, various reactive rebellions took place against new technologies. European countries have tried to solve the shortage of raw materials for the industry with new colonial searches and new wars. All of these developments in the transition process from an agricultural society to an industrial society have led to new social events, revolutions, civil wars, and constitutional movements aiming to change the system (Cetin, 2002).

After each revolution that made a breakthrough in the conflicts between classes, the repressive nature of state power became more and more evident (Kocadaş, 2010b). After a real bourgeoisie revolution (Hobsbawm, 2009) that started in France on July 27, 1830, which led to the establishment of a liberal 
monarchy as a result of the abolition of the Bourbon dynasty and its replacement by the Orleans dynasty (STMA, 1998), the working class would become the main actors of social mobility in Europe and would be the driving force for the next revolutions (STMA, 1998).

The revolutions of 1830 and 1848, which are called the birth pains of the working class, passed into history as early working-class revolutions as much as they appeared as late bourgeois revolutions. The shape of politics in Europe changed between 1830 and 1848 with industrial working-class movements. Great strike movements emerged in England as of the 1820s. In 1934, the "Great National Union" was established, which would gain a great reputation among the working class (Alatli, 2010; STMA, 1998; Tek, 1996). In 1842 there were mass strikes. In 1847 the government passed the 10-hour workday law due to intense pressure from the workers. At the same period, in 1831 and 1834, there were strikes and mass workers' revolts against the government among thread choosers from Lion in France. Also, between 1832 and 1834, Parisian workers joined the uprising (Tilly, 2008).

Table 3: Industrialization Period Strike Waves in the US and Continental Europe (Bush, 2008):

\begin{tabular}{ll}
\hline Place & $\begin{array}{l}\text { Growing Discontents and Years of } \\
\text { Strike }\end{array}$ \\
\hline France & $1893(1879-1880)$ \\
Germany & $1888-1889(1883-1889)$ \\
Great Britain & $1888-1892(1889$ Shipyard Strike) \\
Sweden & $1890-1891$ \\
USA & $1886-1887,1894$ (1880s) \\
\hline
\end{tabular}

Although they were confused about how to do this, the proletariat, which sought to abolish the antagonism between the capitalists and the workers, ${ }^{* *}$ posed a danger to the institutional order only because of their will and their

\footnotetext{
${ }^{* *}$ Proletariat; lower social class, working-class, people belonging to this class (Engels, 2003).
} 
Industrial Revolution and Development As a Model in the Development of Turkish Industry During the Ottoman Empire and the Foundation Period of the Republic

armedness. The 1848 revolution, which took place in an environment where the most broad-based mass unrest of the 19th century came to light, also witnessed the street war of the workers due to the crisis between the government and the opposition (Parker, 2003). The ruling republican bourgeoisie tended to eliminate the more threatening and armed workers (Marx, 1997). Based on these views, it can be said that the increase in this militant attitude in workers' actions also affected some radical organization members and intellectuals. The working class was perceived by socialist intellectuals as the greatest force with the potential to change society. Some theorists began to articulate the emancipation of the working class through its own action. Among them, the writings and ideas of the German philosopher Karl Marx positioned the working class at the center of socialist thought.

\subsection{Effect of the Industrial Revolution on Ottoman Empire and the Republic of Turkey}

The Ottoman Empire, whose economy and production system started to deteriorate in the 17th century due to the deterioration of the land regime and the long-term wars lost, remained far from the capitalist transformation in Europe during this period. (Erdem, 2016). As of the 19th century, the competitive sphere of influence of the industrial revolution spread to the lands of the Ottoman Empire, and economically it came under the hegemony of industrial capitalism. Going under the influence of the industrial revolution, the development line in the country had been different from Europe. While a course was followed from agricultural and brute-force-based production to mechanization in Europe, this situation developed differently in the Ottoman Empire. While large and small industrial enterprises in Europe were established in fields that concern the needs of all areas of daily life, especially textiles, they were built only to meet the needs of the army in the Ottoman Empire at first 
and for a long time (Koktas \& Golcek, 2016). The Ottoman Empire was not completely far from the latest industrial developments in Europe. In the face of the developments, it determined its priority towards meeting the basic needs of the army (Sahin, 2019). However, over time, new enterprises started to operate in different sectors depending on the need.

Table 4: The First Industrial Enterprises Established During the Ottoman Empire (Bozdemir, 2011; Erdem, 2016).

\begin{tabular}{|c|c|c|}
\hline Service Area & Facility Name & $\begin{array}{c}\text { Foundation } \\
\text { Year }\end{array}$ \\
\hline \multirow{4}{*}{ Defense Industry } & Istinye Shipyard & 1856 \\
\hline & $\begin{array}{l}\text { Cebehane-i Amire (War } \\
\text { Ammunition Manufacturing) }\end{array}$ & 1868 \\
\hline & Kayseri Saltpeter Factory & 1891-1892 \\
\hline & Konya Saltpeter Factory & 1896 \\
\hline \multirow{15}{*}{ Textiles and Apparel } & Eyup Spinning Factory & 1827 \\
\hline & $\begin{array}{l}\text { Feshane-i Amire (Imperial Fez } \\
\text { Factory) }\end{array}$ & 1839 \\
\hline & Islimye Broadcloth Factory & 1830 \\
\hline & Islimye Serge Factory & 1840 \\
\hline & $\begin{array}{l}\text { Hereke Fabrika-i Hümayunu } \\
\text { (Hereke Imperial Factory) }\end{array}$ & $1843-1845$ \\
\hline & $\begin{array}{l}\text { Izmit Broadcloth (Wool Fabric) } \\
\text { Factory }\end{array}$ & 1844 \\
\hline & Hereke Broadcloth Factory & 1845 \\
\hline & Bursa Silk Factory & 1846 \\
\hline & $\begin{array}{l}\text { Izmir Muslin Painting and Printing } \\
\text { Factory }\end{array}$ & 1847 \\
\hline & Bakırkoy Cloth Factory & 1850 \\
\hline & $\begin{array}{l}\text { Izmir Fabric Factory- Basmahane } \\
\text { (cloth printing) }\end{array}$ & 1861 \\
\hline & Kula Textile & 1866 \\
\hline & Kirkagac Ginning Factory & 1876 \\
\hline & Izmit Silk Factory & 1880 \\
\hline & Adana National Textile Factory & 1907 \\
\hline \multirow{6}{*}{$\begin{array}{l}\text { Electricity } \\
\text { Generation }\end{array}$} & Dolmabahce Gashouse & 1853 \\
\hline & Beylerbeyi Palace Gashouse & 1862 \\
\hline & Yedikule Gashouse & 1880 \\
\hline & Kadikoy Hasanpasa Gashouse & 1891 \\
\hline & Silahtaraga Power Plant & $1910-1913$ \\
\hline & Uskudar Electricity Factory & 1911 \\
\hline \multirow{2}{*}{$\begin{array}{l}\text { Machinery and } \\
\text { Metal }\end{array}$} & Zeytinburnu Iron Factory & 1843 \\
\hline & Yedikule Railway Factory & 1843 \\
\hline
\end{tabular}


Industrial Revolution and Development As a Model in the Development of Turkish Industry During the Ottoman Empire and the Foundation Period of the Republic

\begin{tabular}{|c|c|c|}
\hline & $\begin{array}{l}\text { Eskisehir Railway Construction } \\
\text { Factory }\end{array}$ & 1894 \\
\hline & Sakir Zumre Stove Factory & $1918-1923$ \\
\hline & $\begin{array}{l}\text { Zeytinburnu Mauser and Cartridge } \\
\text { Factory }\end{array}$ & 1902 \\
\hline & $\begin{array}{l}\text { Zeytinburnu Acid and Ether } \\
\text { Factory }\end{array}$ & 1902 \\
\hline & Zeytinburnu Chemical Factory & 1902 \\
\hline \multirow{8}{*}{ Chemistry } & Beykoz Paper Factory & 1804 \\
\hline & $\begin{array}{l}\text { Pasabahce Sole Trade Spirits } \\
\text { Factory }\end{array}$ & 1822 \\
\hline & Izmir Oil Factory & 1850 \\
\hline & $\begin{array}{l}\text { Beykoz Spermecet (Wax Oil) } \\
\text { Factory }\end{array}$ & 1863 \\
\hline & Second Izmir Oil Factory & 1870 \\
\hline & Tannin (Acid) Factory & 1891 \\
\hline & $\begin{array}{l}\text { Kucukcekmece- Ottoman Matches } \\
\text { Factory }\end{array}$ & 1898 \\
\hline & $\begin{array}{l}\text { Galata Yuksek Kaldirim Battery } \\
\text { Factory }\end{array}$ & 1917 \\
\hline \multirow{2}{*}{ Tiles and Ceramics } & Beykoz Tile Factory & 1845 \\
\hline & $\begin{array}{l}\text { Yildiz Tile Fabrika-i Humayunu } \\
\text { (Imperial Tile Factory) }\end{array}$ & $1890-1892$ \\
\hline \multirow{3}{*}{ Leather and Shoes } & $\begin{array}{l}\text { Beykoz Leather and Shoe Factory } \\
\text { Ottoman }\end{array}$ & 1812 \\
\hline & $\begin{array}{l}\text { Ittihat Saraclik Joint Stock } \\
\text { Company }\end{array}$ & 1913 \\
\hline & Beykoz Shoe Factory & 1884 \\
\hline
\end{tabular}

The attempts of the Ottoman Empire to take action, albeit late, to keep up with the industrial revolution in Europe and to open new businesses by the state or by private enterprise, has faced harsh reactions from time to time among the domestic public and especially among the workers who feared that they would lose their jobs due to the increasing mechanization, similar to its first examples in Europe (Bulbul \& Ozbay, 2007).

The Turkish Republic, which won the struggle for existence starting in 1919 and lasted until 1923, with military victories under the leadership of Mustafa Kemal, and which was wanted to be newly established according to the new administrative methods, gave importance to economic independence as much 
as political independence. In order to revive the collapsed economy, which was inherited from the Ottoman Empire and was generally in the hands of foreigners or non-Muslims, and to bring it to the level of civilization, activities started immediately. Organizing an economics congress in Izmir as the first thing before the signing of the peace treaty that will end the war and even before the proclamation of the Republic, which will become the administrative regime of the country in the future, shows the great importance given by the founding staff to the economy. In the congress, the 12-item "Pact of Economics", which shapes the country's forward-looking economic roadmap, was accepted. For the national economy and national industry, the first bank of Turkey was established in 1924, and the Law for the Encouragement of Industry was enacted in 1927 (ilkin, 2012).

In the first years after the proclamation of the Republic, it is necessary to examine the state's industrial development and economic development activities in two periods. In the first years of the Republic, the state wanted to develop the industry with capitalist capital under the leadership of Europeanstyle private enterprise. However, after the world economic crisis that developed on a global basis in 1929, the private enterprise's investments were insufficient, and the state-centered industrialization period began until the 1950s (Asiliskender, 2009). Only after 1980 in Turkey, with the privatizations that took place under the administration of Turgut Ozal, the influence of the state on the economy was tried to be reduced, and in the meanwhile with the incentives given, it was tried to make the private sector play a dominant role in the industry, and to move to a capitalist free-market economy.

\section{CONCLUSION}

During the establishment of the Republic of Turkey, not only the political independence but also the desire to achieve full independence in the economic 
Industrial Revolution and Development As a Model in the Development of Turkish Industry During the Ottoman Empire and the Foundation Period of the Republic

field was one of the priority issues. Just as the management systems of European countries that reached the level of civilization were taken as a model while creating the new state system, the capitalist economic system based on heavy industry in Europe was taken as a model for the industrialization move to ensure economic development. However, Europe was able to become capitalist as a result of a troubled Industrial Revolution process in the social field with many rebellions, strikes, and boycotts that lasted for long years.

Turkey, on the other hand, tried to integrate its economic system with Europe in the last periods of the Ottoman Empire, yet it did not experience most of the processes that took place there, especially in the social field. As the Republic of Turkey approaches the 100th anniversary of its establishment, it still cannot fully realize its industrialization move, and despite the decisions that cause crises in the business world and social areas from time to time, it yet continues its search for development in the field of industry and technology, especially with a higher acceleration after the 1950s.

\section{REFERENCES}

Akça, G. (2005). "Postmodernite ve Ulus Devlet". Afyon Kocatepe Üniversitesi Sosyal Bilimler Dergisi. 7(2): 232-257.

Aktan, C. C. (1995). "Klasik Liberalizm Neo-Liberalizm ve Libertarianizm." Amme İdaresi Dergisi. 28(1): 3-30.

Alatlı, A. (2010). Batıya yön veren metinler. (Cilt 4). İstanbul: İlke Eğitim ve Sağlık Vakfı Yayınları.

Alganer, Y. \& Çetin, M. Ö. (2007). “Avrupa'da Birlik ve Bütünleşme Hareketleri (I)”. Marmara Üniversitesi i.i.i.B.F. Dergisi. 23(2): 285-309.

Aron, A. (1974). Sanayi toplumu. İstanbul: Boğaziçi Yayınları. 
Asiliskender, B. (2009). "Cumhuriyet Sonrası Kalkınma Hareketi Olarak Sanayileşme ve Mekânsal Değişim". Türkiye Araştırmaları Literatür Dergisi. 7(13): 153-169.

Berce, Y. (2003). Modern Avrupa'da ayaklanmalar ve devrimler xVI-XVIII yüzyıllar. (M. Cedden, Çev.) Ankara: İmge Yayınları.

Bush, C. M. (2008). "Reformcular Ve Devrimciler: Sistem Karşıtı Hareketlerin Yükselişi ve Iktidar Paradoksu 1848-1917". İçinde W. G. Martin (Eds.) Toplumsal Hareketler (1750-2005). (ss. 87-140). İstanbul: Versus Yayınları.

Bülbül, Y. \& Özbay, R. D. (2007). “Osmanlı İmparatorluğu’nda Teknolojiye Karşı Direncin İktisat Tarihi". İş Güç Endüstri İlişkileri ve İnsan Kaynakları Dergisi. 9(4): 19-41.

Bonnard, A. (2004). Antik Yunan uygarlığı I, (K. Kurtgözü. Çev.) İstanbul: Evrensel Basım Yayın.

Bookchin, M. (2012). Köylü isyanlarından Fransız devrimine. Ankara: Dipnot Yayınları.

Bozdemir, M. (2011). Osmanlı'dan Cumhuriyet'e endüstriyel mirasımız. İstanbul: İstanbul Ticaret Odası Yayınları.

Canbolat, ì. (2007). “Avrupa Birliği’nin Kuruluş Felsefesi ve Yeni Avrupa’nın Yapılanması". İçinde E. Efegil \& M. S. Erol (Eds.) Türkiye-AB iliş̧kileri, Avrupa'nın Genişlemesi, Müzakere Süreci ve Batılılaşma Sorunsalı. (ss. 926). Ankara: Orion Yayınları.

Cihangir, F. (2004). "Bati'nin ve Batililaşmanin Yeni Yüzü". Köprü Dergisi. 85(2): 29-58.

Deane, P. (2000). Illk sanayi inkılabı. (T. Güran, Çev.) Ankara: Türk Tarih Kurumu Yayınları.

Delanty, G. (2005). Avrupa'nın icadı. (H. İnaç, Çev.) Ankara: Adres Yayınları.

Duman, M. Z. (2008). “Fransız Devriminin Politik Sonuçları Ve Tocqueville'in Devrime Ilişkin Görüşleri”. Sosyoloji Dergisi. 19, 104-119. 
Industrial Revolution and Development As a Model in the Development of Turkish Industry During the Ottoman Empire and the Foundation Period of the Republic

Erdem, E. (2016). "Sanayi Devriminin Ardından Osmanlı Sanayileşme Hamleleri: Sanayi Politikalarının Dinamikleri ve Zafiyetleri". Erciyes Üniversitesi Iktisadi ve İari Bilimler Fakültesi Dergisi. 48(2): 17-44

Gök, A. K. (2007). "Vergi Direncinin Gelişimi". Marmara Üniversitesi i.i..B.F. Dergisi. 22(1): 143-163.

Göz, A. (2010). "Eski Yunan'dan Sanayi Toplumuna Siyasal Iktidar-Siyasal Muhalefet Ilişkilerinden ve Bu Ilişkilerin Sonuçlarından Örnekler". Yerel Siyaset Dergisi. 4(42): 77-80.

Halecki, O. (2000). Borderlands of western cIvilization: ahistory of east central Europe. Simon Publications.

Halis Çetin, H. (2002). "Liberalizmin Tarihsel Kökenleri". Çukurova Üniversitesi iktisadi Ve Idari Bilimler Dergisi. 3(1): 79-96.

Hamitoğulları, B. (1986). Çağdaş iktisadi sistemler. Ankara: Savaş Yayınları.

Hayes, C. (1938). Ingiltere'de sanayi inkılabı. (Ö. M. Doğrul, Çev.) İstanbul: Tan Evi Cep Kitapları Serisi.

Hobsbawn, E. J. (1998). Devrim Çağı (1789-1848). (B. S. Şener, Çev.) Ankara: Dost Kitabevi.

Hobsbawm, E. J. (1999). Imparatorluk çağı, 1875-1914. (V. Aslan, Çev.) Ankara: Dost Kitabevi.

Hobsbawm, E. J. (2009). Fransız devrimine bakış. (O. Akınbay, Çev.) İstanbul: Agora Kitaplığı Yayınları.

İlkin, A. (1970-71). "Türkiye'de Sanayi Politikası (1923-1973)". İstanbul Üniversitesi iktisat Fakültesi Mecmuası. 30(1-4): 377-423.

Karluk, R. (2007). Avrupa Birliği ve Türkiye. İstanbul: Beta Yayınları.

Kocadaş, B. (2010a). "Küreselleşme Tehdidi ve Türkiye". İçinde M. Talas, B. Kara (Eds.). Dünden Bugüne Küreselleşme Yerelleşme ve Türkiye. (ss. 157178293). Ankara: Gazi Kitabevi.

Kocadaş, B. (2010b). Toplum toplumsal yapı ve kurumlar. İstanbul: Doğu Kütüphanesi. 
Kocadaş, B. (2021). "Kent(Leşme) Suç Ve Sapma”. İçinde Ü. Şentürk (Eds.). Kent Sosyolojisi Üzerine Senfonik Okumalar. (ss. 271-293). Çanakkale: Paradigma Akademi.

Köktaş, M. K. \& Gölçek, A. G. (2016), “Endüstri Devrimi ve Osmanlı İmparatorluğu: Askeri Fabrikalaşma Örneği". Ömer Halisdemir Üniversitesi İktisadi ve İdari Bilimler Fakültesi Dergisi, 9(4): 95-105.

Küçükkalay, M. (1997). "Endüstri Devrimi Ve Ekonomik Sonuçlarının Analizi”. Süleyman Demirel Üniversitesi (SDÜ), İktisadi ve İdari Bilimler Fakültesi (iiBF) Dergisi, Sayı 2(2): 51-68.

Lee, S. L. (2004). Avrupa tarihinden kesitler 1789-1980. (S. Aktur, Çev.) Ankara: Dost Yayınları.

Maillet, M. (1983). Iktisadi olayların evrimi. (E. Tokdemir, Çev.) İstanbul: Remzi Kitabevi.

Mansel, A. F. (1984). Ege ve Yunan tarihi. Ankara: Türk Tarih Kurumu Yayınları.

Marks, K. (1997). Fransa'da iç savaş. (K. Somer, Çev.) Ankara: Sol Yayınları.

Marks, K. \& Engels, F. (2003). Komünüzmin ilkeleri. Seçme Yazılar. (Cilt I). (M. Ardos vd. Çev.). Yer Belirtilmemiş: Eriş Yayınları.

Mitropolski \& Zubritski, Y. \& Kerov, V. (2006). Ilkel topluluk, köleci toplum, feodal toplum. (S. Belli, Çev.) Yer Belirtilmemiş: Eriş Yayınları.

More, C. (2000). Understanding the Industrial revolution. London: Taylor \& Francis Group.

Ökte, K. S. (2008). “Antik Çağda Iktisadi Düşünce”. Elektronik Sosyal Bilimler Dergisi. 7(27): 37-62.

Önder, T. (2003). Ekoloji, toplum ve siyaset. Ankara: Odak Yayınevi.

Parker, D. (2003). Batıda devrimler ve devrimci gelenek 1560-1991. (K. İnal, Çev.) Ankara: Dost Kitabevi.

Pierce, A. (2005). The industrial revolution. ABDO Publishing Co.

Plutarkhos. (2001). Gracchus Kardeşler. (S. Sandalcı, Çev.) İstanbul: Belge Yayınları. 
Industrial Revolution and Development As a Model in the Development of Turkish Industry During the Ottoman Empire and the Foundation Period of the Republic

Rostow, W. W. (1970). "Sanayi Devrimi Nasıl Başladı". İstanbul Üniversitesi İktisat Fakültesi Mecmuası. 30(1-4): 255-278.

Savaş, V. F. (2000). iktisadın tarihi. Ankara: Siyasal Kitabevi.

Selik, M. (1998). Iktisadi doktrinler tarihi. İstanbul: Gerçek Yayınları.

Smith, N. (2009). The industrial revolution. London: Evans Brothers Lt.

Stark, (1994). iktisadi düşünce ve toplumsal gelişme. (M. Özel, Çev.) İstanbul: İz Yayınları.

Sosyalizm ve Toplumsal Mücadeleler Ansiklopedisi. (1988). (Cilt 8, S.2506-2507). İstanbul: İletişim Yayınları.

Şahin, R. (2019). "Sanayi Devrimi Osmanlı İmparatorluğu'nda Neden Başlamadı?" Business, Economics and Management Research Journal BEMAREJ. 2(1): 1-16.

Tek, Ü. (1996). "Avrupa Birliğinde Sendikalar". Ekonomik Yaklaşımlar Dergisi. 7(20): 49-76.

Tilly, C. (2008). Toplumsal hareketler 1768-2004. (R. Yılmaz, Çev.) İstanbul: Babil Yayınları.

Umur, Z. (1982). Roma Hukuku. İstanbul: Fakülteler Matbaası.

Veysal, Ç. (2006), Savaşın felsefesi. İstanbul: Etik Yayınları.

William L. Westermann, W. L. (1955). "The Slave Systems of Greek and Roman Antiquity". The American Philosophical Society. 50-55.

Yalvaç, F. (2007). "Rousseau'nun Savaş ve Barış Kurami: Adalet Olarak Barış". Uluslararası İlişkiler Dergisi. 4(14): 121-160.

Yıldırım, E. (2007). Avrupa Bütünleşmesinin Düşünsel Temelleri. Yayınlanmamış yüksek lisans tezi, İstanbul Üniversitesi Sosyal Bilimler Enstitüsü. 


\section{GENiş ÖZET}

Giriş: 18. yüzyıldan İngiltere'de başlayarak Avrupa'ya yayılan Sanayi Devrimi, 19. ve 20. Yüzyıl dünya tarihi içerisinde devletler arası ilişkileri belirleyen, sosyal, ekonomik ve siyasal sonuçları olan en önemli toplumsal olaydır. Artan makinalaşma ile birlikte artan üretimin pazarlanması ve hammadde arayışları devletlerarası yeni rekabet sahalarına neden olmuş, bu rekabetler sonucu çıkan çıkar çatışmaları nedeniyle çıkan savaşlarda yeni devletler kurulmuş, yeniden sınırlar çizilmiştir. Osmanlı Devleti'nde bu yeni dünya düzeninin kurbanı olmuştur. Kaybedilen savaşlar sonucu iyice zor duruma düşen devlet, ilk önce askeri alanda olmak üzere yeni üretim alanları kurmaya çalışarak Sanayi devrimine ayak uydurmaya çalışmıştır. Osmanlı Devleti'nin yıkılması sonrası Lozan Antlaşması ile kurulan Türkiye Cumhuriyeti endüstriyel kalkınmayı ve tam ekonomik bağımsızlığı, siyasi bağımsızıı kadar önem vermiş ve ilk andan itibaren ülkede bir sanayi atılımı/devrimi yapılması gayretine girişilmiştir.

Metot: Bu araştırmanın amacı, önce Osmanlı Devleti son dönemlerinde ve sonradan da Türkiye Cumhuriyeti'nin ekonomik olarak kalkınma modeli olarak seçtiği sanayi inkılabına ilham veren Avrupa'daki Sanayi devriminin oluşumu, gelişimini ve Türkiye'ye yansımalarını ortaya koymaktır. Bunun için ilgili literatür taranmış ve belgeler toplanmış, ilgili araştırmalar elde edilmiş, çeşitli kaynaklarda yayınlanan makaleler ve kaynaklar incelenmiş ve elektronik ortamda yer alan metinlerden yararlanılmıştır.

Bulgular (Sonuçlar): Avrupa'da sanayi Devrimi birden ortaya çıkmamıştır. Uzun yıllar süren bir toplumsal hareketliliğin sonucudur. Özellikle 15. Yüzyıldan itibaren kent yaşamının gelişmesi ve buna bağlı olarak ticaretin gelişmesi sonucu sosyal yapı ve kilise gibi iktidarları etkileyen güç odakları değişmeye başlamıştır. $\mathrm{Bu}$ değişim uzun ve çoğu zaman da halk ayaklanmaları sonucu olmuştur. Özellikle yeni keşfedilen coğrafyalardan gelen sermaye ve hammadde bolluğu Avrupa'daki ticaret ortamını daha da değişikliğe uğratmıştır. Üretimde makinalaşmanın başlaması ile birlikte kötü koşullarda çalışmanın getirdiği zorluklar işçi sınıfının doğuşunu hazırlar iken, öbür taraftan da hammadde arayışları, sert rekabet ve kalıcı Pazar arayışları ulus devletler haline dönüşmeye başlayan Avrupa'da devrimlere ve büyük savaşlara yol açar. Bu rekabet ortamından, pazar ve hammadde rekabetinden en çok etkilenen ülkelerden birisi de Osmanlı Devleti ve yerine kurulan Türkiye Cumhuriyeti'dir. 
Industrial Revolution and Development As a Model in the Development of Turkish Industry During the Ottoman Empire and the Foundation Period of the Republic

Sonuç ve Tartışma: İngiltere' de başlayarak kısa sürede tüm Avrupa'ya yayılmaya başlayan makinalaşma ve endüstrileşme, bu bölgede uzun süreli yaşanmakta olan bir toplumsal dönüşümün sonucudur. Avrupa'da kilise ve yönetici soylu kesimin iradesi dışında tabandan yükselen bir değişimin ve dış konjonktürün olumlu yansımalarının sonucudur. Avrupa'daki ekonomik gelişmelerin sonucunda yaşanan atılımı yakalamak isteyen Osmanlı Devleti, son dönemlerinde ve akabinde kurulan Türkiye Cumhuriyeti'nin ilk yıllarında artan sanayileşme gayretleri, tabandan gelen bir toplumsal dönüşümün doğal sonucu olmaktan ziyade, halkın başat olmadığı, yönetici elit kesimlerin yönlendirmesi sonucu gerçekleştirilmeye çalışılan bir tavan hareketidir.

Anadolu'da da toprak sisteminin bozulması ve kaybedilen savaşların ağır maliyetleri sonucu ekonomik olarak gerileyen toplumda zaman zaman düzene karşı başkaldırı girişimleri olmasına karşın, bunlar hiçbir zaman ekonomide bir liberalleşme veya kapitalist sistemin gelişmesine, ticari faaliyetlerin artmasına yol açacak sonuçları olmamıştır. Osmanlı Devleti Avrupa'da yaşanan gelişmelerden geri kalmamak üzere devlet eliyle önce askeri alanlarda sanayi tesisleri kurmaya başlamıştır. Zamanla az da olsa sayıları artmaya başlayan fabrikalar ise genelde yabancıların veya gayrimüslimlerin elindedir.

Mustafa Kemal Atatürk önderliğinde kurulan Türkiye Cumhuriyeti'nin ilk yıllarında hükümetler ekonomik bağımsızlık ve sanayinin gelişmesi konuları üzerinde ciddiyetle durmuştur. Kurtuluş mücadelesinin askeri neticesi kesinleşmiş ancak daha devletler arası kalıcı bir barış antlaşması imzalanmadan, devletin yönetim ve siyasi yönü tam netleşmemişken düzenlenen İktisat kongresi ile yeni yönetim sanayileşme ve kalkınmaya verdiği önemi göstermekteydi. Buna göre hammaddesi ülke sınırları içinde olan sanayi kuruluşları acilen kurulacak, geleneksel yöntemlerle üretim yapan küçük sanayi işletmeleri makine üretimine yönlendirilerek fabrikalaşmaları özendirilecek, bunu gerçekleştirmek için ucuz kredi sağlayacak milli bankalar kurulacak, sendikalaşmaya müsaade edilerek işçilerin haklarının da korunması gibi ekonomide Avrupai tarzda liberal bir dönüşüm sağlanmak isteniyordu. Türkiye Cumhuriyeti, Osmanlı Devleti'nden devralınan sınırlar içinde ülkede kurulu sanayi tesislerinin sahipleri olan yabancı veya gayrimüslimlerin mallarına el koymak yerine, kanunlara uymaları şartıyla ticari faaliyetlerde bulunmalarını teşvik etmişti. Bu sayede ülkede özel teşebbüsün ve ticari faaliyetlerin artması hedeflenmekteydi.

Bu dönemde endüstriyel alanların gelişmesi için Osmanlı Devleti’nden farklı ve Avrupa'dakine benzer şekilde ekonomi de toplumun aktif rol alması istenmiş, özel teşebbüsün güçlendirilmesi yoluyla gelişim modeli benimsenmişti. Ancak 1929 yılında yaşanan ekonomik kriz nedeniyle hükümetler mecburen kamunun liderliğini yaptığı, devletin çeşitli illerde farklı fabrikalar açması yoluyla 
sanayileşmeye çalışılmıştır. Bu nedenle ülke bütçesinin elverdiği ölçüde ülkenin çeşitli bölgelerinde yetiştirilen ürün veya bulunan hammaddeye göre o civarda devlet eliyle çeşitli büyük fabrikalar açılmış hem bölgesel kalkınma ile ticari faaliyetleri arttırma hem de yörede yaşayan insanlara yeni iş kapıları oluşturma gayretine girilmişti. Bu durum uzun süre bu şekilde devam etmiş, 1950'li yıllarda biraz ivme kazanmış ancak sanayileşmede yerlilerin özel sektörlere girişi ve istendik şekilde ön plana çıkmaya başlaması, özelleştirmelerin arttığı 1990'lı yılları bulmuştur. Avrupa'da yaşanan sanayi devriminin öncesi ve sonrasına benzer şekilde halkın ticari faaliyetlerde başat rol oynamaya başlaması ile Avrupa'daki kadar geniş katılımlı ve uzun bir süreç sonu olmasa da Türkiye'de devlet tarafından olduğu kadar halk tarafından da sanayileşmenin önemi kavranmıştır. 